УДК 2:316.74

DOI https://doi.org/10.32837/apfs.v0i29.953

В. В. Мельничук

ORCID ID: https://orcid.org/0000-0003-1569-3201

кандидат філософських наук,

доцент кафедри суспільних наук

Поліського національного університету

О. М. Шевченко

ORCID ID: https://orcid.org/0000-0002-1917-9472 кандидат психологічних наук, доцент, доцент кафедри суспільних наук Поліського національного університету

\title{
ТРАНСФОРМАЦІЯ РЕЛІГІЙНОСТІ В УМОВАХ УРБАНІЗАЦІЇ: СОЦІАЛЬНО-ФІЛОСОФСЬКИЙ АНАЛІЗ
}

Постановка проблеми. Однією з провідних тенденцій розвитку сучасного світу є прискорення процесів урбанізації, що спричиняє значні зміни в бутті людини та суспільства. Міський спосіб життя формує тип особистості зі специфічними рисами та особливостями поведінки. Місто трансформувало людину, оточивши здебільшого матеріальними цінностями, поставивши в залежність від них, зробивши спілкування переважно формалізованим та нетривалим, що значно вплинуло i на духовну сферу.

У цьому контексті зауважимо, що досить поширеною є точка зору, згідно з якою вважається, що сучасна урбанізація посилила секуляризаційні процеси. Оскільки спосіб життя людини у місті формує нову систему ціннісних орієнтацій, які досить часто не залежні від релігії. Проте навіть за таких умов церква була і залишається одним 3 найвпливовіших соціальних інститутів. Зважаючи на вищезазначене, вивчення впливу урбанізаційних процесів на трансформацію релігійності людини, а також суспільства загалом є актуальним і доцільним.

Аналіз останніх досліджень і публікацій. Окреслена проблематика стала об'єктом дослідження українських та закордонних науковців. Дослідженню зміни функціональності релігії під впливом секуляризаційних процесів присвячено праці українських учених А. Колодного, Л. Филипович. Проблеми впливу секуляризації, яка характеризує сучасний урбанізований світ, на розвиток релігійної сфери також були розглянуті у роботах таких дослідників, як Х. Казанова, Ч. Тейлор, а український науковець М. Паращевін розглядає нинішній етап цього процесу як постсекуляризацію.

Л. Вірт та Г. Зіммель свої дослідження присвятили аналізу тенденцій розвитку урбанізованого суспільства, зокрема і в контексті світоглядних, у тому числі релігійних, трансформацій. Цікавими $е$ наукові розвідки I. Богдановського про поширення у сучасному суспільстві нових релігій та їх вплив на людину, а також О. Дарморіз, яка проаналізувала, як змінюється релігія та релігійність під впливом інформаційних технологій. Ця тематика потребує подальшого вивчення, адже, незважаючи на значну зацікавленість нею, комплексного дослідження впливу урбанізації на зміну релігійності здійснено не було.

Метою дослідження $є$ вивчення впливу урбанізаційних процесів на особливості формування, рівень релігійності людини та суспільства, а також специфіки її трансформації.

Основний матеріал дослідження. Згідно 3 даними соціологічних досліджень, в Україні церква залишається одним 3 лідируючих соціальних інститутів за рівнем довіри (поряд з волонтерськими організаціями і Збройними силами). Хоча порівняно з 2010 р., коли рівень суспільної довіри до церкви досяг максимуму $(73 \%)$, нині цей показник є нижчим - $60 \%[7$, с. 8].Тобто, зважаючи на сучасні суспільні процеси, роль релігії змінюється, але вона не зникає і не втрачає свого впливу.

Проблемі трансформації функціональності релігії значну увагу у своїх дослідженнях приділяє українська вчена Л. Филипович, яка зазначає, що поряд із їі традиційними функціями виникають нові, що зумовлено соціально-культурною та духовною реальністю. Нинішній час характеризується «великим поверненням» релігії у глобальну політику, міжнародні відносини, державотворення, індивідуальне та соціальне буття людини. За таких умов релігія починає виконувати свої функції у господарсько-економічній, освітньо-просвітницькій, науково-культурній, військово-патріотичній та інших сферах. Вона використовується як чинник збереження національної ідентичності; творення нових смислів для історичного прогресу та формування нових 
стратегій соціального розвитку [10, с. 64-66]. 3 цього приводу М. Паращевін зауважує, що в контексті суспільної значущості релігії варто враховувати: в окремих кризових ситуаціях вона долучається до тих процесів, які виникають поза нею, і не пов'язані з нею. Це зумовлюється тим, що релігія зберігає певну непомітну латентну значущість; існує як глибинна цінність, як певний архетип свідомості, який у нестандартних ситуаціях може актуалізовуватися. Але 3 цього ж випливає, що потенціал релігії як соціального інституту суттєво залежить від сукупності наявних обставин [8, с. 338-335], поява яких зумовлюється тенденціями суспільного розвитку, однією 3 яких є урбанізація.

Домінуюча роль міста у розвитку сучасної цивілізації, особливо підкреслена технологічним прогресом, призвела до поширення міського способу життя за територіальні межі міста. На нашу думку, мають рацію науковці, які вважають, що у сучасних умовах не варто ототожнювати урбанізм із фізичними межами міста, розглядаючи його як обмежений простір. Урбанізація - це не просто зростання міст та кількості міського населення, а сукупність характеристик, що відображають спосіб життя, який вважається міським [2, с. 96-97]. Тому це беззаперечно зумовлює зміни особистості, iї духовності та ставлення до соціальних інститутів, зокрема й релігійних.

Дослідник урбанізму Л. Вірт звертав увагу на те, що до вивчення цього феномена як специфічного способу життя можна підійти з трьох взаємопов'язаних точок зору, розглядаючи його як: 1) фізичну структуру; 2) як систему соціальної організації; 3) як набір установок та ідей, а також особистостей, залучених у типові форми колективної поведінки, що підпорядковуються характерним механізмам соціального контролю [2, с. 112]. В контексті нашого дослідження ми звернемо увагу здебільшого на третій аспект, розглянемо, які особистісні та суспільні зміни відбуваються під впливом окреслених тенденцій, зокрема у сфері релігійності.

У містах переважає раціональність, порівняно 3 невеликими поселеннями, де більш необхідним $е$ прояв відносин, заснованих на почуттях, які формуються у спокійній атмосфері рівноваги незмінних звичок, а розум допомагає розібратися у протилежностях явищ, дає змогу встигати за ритмом зовнішніх явищ. Цим типовий житель міста (хоча й представлений багатьма модифікаціями) створює собі засіб для захисту від протирічь зовнішнього світу, реагуючи на них не почуттями, а розумом. Це є своєрідним захистом суб' єктивного життя від насилля великого міста [4, с. 2]. Адже місто, його динамічність постійно змушує людину долати виклики, зумовлені специфікою цього способу життя.
Поверхневість, анонімність і швидкоплинність міських соціальних зв'язків дають змогу зрозуміти раціональність міських жителів, які зазвичай пов'язані відносинами корисності, i розглядають взаємодію один з одним як засіб для досягнення цілей. Хоча індивід досягає певного рівня свободи від особистого та емоційного контролю, водночас він втрачає почуття участі, що супроводжує життя в інтегрованому суспільстві [2, с. 99]. В урбанізованому суспільстві індивід відчуває себе незалежним, що є результатом взаємної замкнутості і байдужості як складників умов духовного життя жителів міста, де фізична близькість i скупчення лише підкреслюють духовну віддаленість. Це інша сторона свободи, адже ніде не відчуває людина себе такою одинокою як у натовпі великого міста [4, с. 8-9]. Сусідство дивергентних особистостей і способів життя зумовлює почуття терпимості до відмінностей, які можна розглядати як необхідні передумови раціональності, які призводять до секуляризації життя [2, с. 102]. Тому секуляризацію вважають атрибутом урбанізованого суспільства.

Розуміння секулярності в контексті громадських просторів, які позбулися Бога чи будь-якого посилання на найвищу реальність, надає канадський філософ Ч. Тейлор. Він зазначає, що принципи та норми, а також рішення в різних сферах життедіяльності (економічній, політичній, культурній, професійній, оздоровчій) не пов'язані з Богом чи релігійними переконаннями, а обгрунтовуються лише раціональністю: в економіці - це максимальний прибуток, у політиці - користь для найбільшої кількості громадян тощо. Це контрастує із попередніми періодами. Проте значна більшість людей усе ще вірять у Бога й дотримуються релігійних практик. Він наголошує, що секулярність треба розглядати насамперед як становище віри у суспільстві. У цьому контексті поворот до секулярності є рухом від суспільства, де віра в Бога була незаперечною і не піддавалася жодному сумніву, до такого, де віру розуміють як певний варіант вибору поряд з іншими [9, с. 15-16]. Урбанізація в Європі принесла звільнення від примусової релігійності, зумовивши секуляризацію, адже бути сучасним означало бути секулярним та нерелігійним. Проте в інших контекстах, зокрема і в сучасній Україні, урбанізація може спонукати до зростання релігійного плюралізму та релігійного відродження [5, с. 7].

Якщо говорити про Україну, то необхідно звернути увагу на те, що релігійність українців, яка здавна здебільшого була орієнтовна на сільський спосіб життя, на думку українських науковців А. Колодного, Л. Филипович, поступово втрачає свою антеїстичну окресленість. Це пов'язано передусім зі змінами у соціальній структурі українського суспільства, яке перетворилося на 
урбанізоване, оскільки більшість українців проживають у містах, де релігійна громадська думка втратила контролюючу роль. Відповідно, змінилися традиційні форми вияву релігійності, яка у сучасних умовах характеризується відносною пасивністю віруючих у відвідуванні культових споруд, вибір зручного часу, здебільшого дні великих свят, неділя тощо. За таких умов намагання механічно відновити традиційні форми вияву релігійності є недоцільними.

Необхідно також відзначити, що за останні десятиріччя до релігії звернулося багато невіруючих у минулому, переважно міських жителів, яким прищепити традиційну, сформовану на селянській основі релігійну духовність, вже просто неможливо. Під впливом атеїзму впродовж багатьох років до релігії вони ставляться з позицій раціональності, доцільності, практичності [6]. Ми погоджуємося, що традиційна духовність українців, зокрема і її релігійний складник, переживає кризу, проте формується інша, заснована на нових принципах. Вважаємо, що цей процес $\mathrm{e}$ закономірним, адже змінюються історичні умови, суспільство, сама людина, тому будь-яка релігія для продовження свого існування певною мірою повинна трансформуватися, водночас не втративши своєї сутності.

Л. Филипович зауважує, що немає достатніх підстав вважати Україну секулярною країною, адже українці ніколи не жили у ситуації виключно секулярній або релігійній. Вона скоріше є псевдосекулярною, де секулярність встановлена силоміць, під тиском диктаторського режиму. Тому нинішній період духовного розвитку України варто розглядати в контексті двох взаємодоповнюючих процесів: з одного боку, життя в Україні дедалі релігієзується, нехай навіть зовнішньо, за кількісними показниками, а 3 іншого - вибудовується справжня секулярність, що грунтується не на боротьбі з релігією, не на протиставленні, а на розмежуванні функціонального призначення i сфер впливу релігійного та світського. Проте дослідниця наголошує, що осмислення взаємодії релігії з іншими соціальними інститутами, того, як зростає її затребуваність, помилково призводить до висновку про десекуляризацію українського суспільства. «Наступ» релігії на світське життя є дещо перебільшеним, а десекуляризаційні процеси дещо абсолютизовані, навіть якщо йдеться не про тотальну, а часткову десекуляризацію. На її думку, таке дуалістично-антагоністичне сприйняття релігійного і секулярного вже не $є$ продуктивним [11, с. 196]. Отже, сучасна соціальна реальність є дихотомічною, а протиставлення секулярного і релігійного не відповідає тенденціям розвитку сучасного світу.

Хоча може скластися думка, що нинішне суспільство спроможне існувати без релігії, яка стає виключно приватною, проте більшість людей досі чи знову вірять в Бога, а традиційні й нові релігії продовжують функціонувати [5, с. 16-17]. В. Паращевін вважає, що нинішню добу можна охарактеризувати як постсекулярну, якій притаманні певні ознаки, зокрема:

визнання збереження або домінування секулярного розуміння світу, проте в якому релігії відводиться певна роль, що можна вважати наслідком неспроможності секулярності та секуляризму стати «тотальним» баченням світу, у результаті чого релігія отримала можливості у тих сферах, 3 яких вона була витіснена секуляризацією;

обмеженість застосування концепції «постсекулярності» лише стосовно суспільств, які пройшли секуляризацію;

постсекулярність не варто ототожнювати 3 реваншом релігій, які були витіснені секуляризаційними процесами, хоча вона призвела до їх трансформації, зокрема і таким чином, що вони набували певних рис світських структур та ідеологій. I такі зміни відбуваються як у середовищі традиційних релігій, так і у зв'язку з появою різноманітних нових релігійних учень та рухів [8, с. 117-118].

Справді, однією з тенденцій розвитку сучасного урбанізованого світу є поширення нетрадиційної релігійності, адже релігійні пошуки активізуються здебільшого в умовах криз та трансформацій суспільного життя, коли раціональні способи не дають можливості осягнути суспільне та індивідуальне буття, посилюється його нестабільність. Одним із чинників посилення нестабільності є постійно зростаючий темп життя, що найбільш помітно проявляється саме у містах.

За таких умов, як зазначає I. Богдановський, єдиний вихід людина вбачає у пошуках містичних переживань. У перехідні періоди цивілізаційного розвитку у суспільстві виникають сприятливі умови для маніпуляцій масовою свідомістю, адже потреба індивідів у цілісній системі координат в умовах прогресуючої суспільної аномії є настільки великою, що вони легко можуть піддатися впливу політичних, філософських або релігійних ірраціональних доктрин $[1$, c. 6$]$. Оскільки сучасне людство постало перед великою кількістю проблем, то виникає необхідність пошуку такої системи цінностей, яка могла б стати універсальною. Однією з яких, на думку сучасних науковців, може стати спільна для більшості людства релігія. В умовах загострення економічних, екологічних, продовольчих та інших глобальних проблем релігія може перетворитися на один з головних інструментів встановлення нового світового порядку [1, с. 335$]$. Проте лише за умови проведеної до кінця економічної та політичної глобалізації стане реальним створення єдиної офіційної світової релігії. На цю роль 
можуть претендувати вже наявні світові релігії. Також це може бути одна з наявних зараз або утворена у майбутньому синкретична неорелігія [1, с. 339]. На нашу думку, окреслені процеси можуть відбуватися у довгостроковій перспективі, натомість у нинішніх умовах виникають не лише нові релігійні рухи, але й відбувається трансформація наявних релігій.

В урбанізованому суспільстві змінюється не лише релігія, але і способи їі поширення та, відповідно, формування релігійності. В умовах, коли традиційні методи втрачають вплив і дієвість, закономірно виникають нові, які відповідають запитам сучасної людини. Тому хочемо звернути увагу на Інтернет як один з домінуючих засобів комунікації, в тому числі й релігійної, що значною мірою впливає і на формування релігійності.

Спілкування сучасних людей відбувається в режимі відкритості та загальнодоступності, в комунікативному середовищі відсутні територіальні, ієрархічні та часові межі. Під впливом науково-технічного прогресу людина змінює також усталені форми спілкування 3 надприродним i продукує нові форми релігійності, які більшою мірою відповідають сучасному стану суспільного та наукового розвитку.

Це може виявлятися у двох напрямах: з одного боку, дає можливість для трансформації традиційних релігій з метою відповідності потребам сучасної людини; з іншого - поява нових релігійних явищ - кіберрелігій. У середовищі останніх змінюється свідомість та самосвідомість людини, адже реальне спілкування з вищою силою замінюється віртуальним, а отже, формує уявлення не про справжнє спілкування, а швидше - гру, яку можна зупинити в будь-який час [3, с. 77-79]. На нашу думку, така проблематика є дуже актуальною і потребує більш детального вивчення і може стати об'єктом окремого дослідження, адже атрибутом сучасної урбанізації є віртуалізація буття людини, переміщення їі спілкування 3 реальної площини у віртуальний вимір.

Висновки. Отже, сучасний етап суспільного розвитку характеризується трансформаційними процесами в усіх сферах життя людини, одним з яких є урбанізація, що в нинішніх умовах відбувається швидкими темпами. Окреслені тенденції впливають як на індивідуальне, так і на соціальне буття, змінюють особливості функціонування соціальних інститутів. Проте навіть в умовах секуляризації, яка характерна для урбанізованого суспільства, релігія не втратила своєї суспільної значущості та впливу на духовність людини. Такий етап можна охарактеризувати як постсекулярний, коли релігія не зникає, а тран- сформується. Відбувається розподіл сфер впливу релігійного і світського, хоча водночас релігія залучається в різні сфери суспільного буття.

Долаючи виклики, які постають в урбанізованому суспільстві, що грунтується на раціональних началах, людина водночас апелюе і до трансцендентного. Шукаючи нові ціннісні орієнтири, вона звертається до релігії, формуючи новий тип релігійності, який характеризується більшою анонімністю, приватністю, вибірковістю. В таких умовах виникають нові релігії, які більш адаптовані до сучасних умов та вимог, водночас змінюють свою функціональність і традиційні релігії. Тому трансформуються засоби формування релігійності, зокрема і під впливом віртуалізації. Таким чином, в урбанізованому суспільстві релігія не втрачає свого значення та затребуваності, актуалізується проблема зміни їі функціональності, а тому і формування релігійності, яка значною мірою зумовлена соціальними умовами.

\section{Jimepamypa}

1. Богдановський І.В. Філософський аналіз феномена нетрадиційної релігійності: соціальний і психологічний аспекти : монографія. Ірпінь, 2012. 373 с.

2. Вирт Л. Урбанизм как образ жизни. Избранные работы по социологии / пер. с англ. В.Г. Николаева. Москва : ИНИОН РАН, 2005. С. 93-118.

3. Дарморіз О. Формування людини нового типу та трансформація релігійності в інформаційному суспільстві. Humanitarian Vision. 2016. Volume 2, Number 2. P. 75-80.

4. Зиммель Г. Большие города и духовная жизнь. URL: http://www.ruthenia.ru/logos/number/34/02.pdf (дата звернення: 16.03.2021).

5. Казанова Х. По той бік секуляризації. Релігійна та секулярна динаміка нашої глобальної доби / пер. 3 анг. О. Панича. Київ : ДУХ І ЛІТЕРА, 2017. 264 с.

6. Колодний А., Филипович Л. Релігія в контексті духовного відродження України. URL: https://uars. info/prints/ur/02/3.pdf (дата звернення: 16.03.2021).

7. Особливості релігійного і церковно-релігійного самовизначення громадян України : тенденції 2000-2020 pp. (Інформаційні матеріали). Київ. 2020, $110 \mathrm{c.}$

8. Паращевін М. Релігія в Україні: траєкторія інституційних змін : монографія. Київ : Ін-т соціології НАН України, 2017. 362 с.

9. Тейлор Ч. Секулярна доба. Книга перша / пер. 3 англ. О. Панича. Київ : Дух і літера, 2013. 664 с.

10. Филипович Л. Трансформації функціональності релігії у сучасну добу : причини та наслідки. Релігія в проблемах їі структури і функціональності : наукова збірка / за ред. А. Колодного. Київ : Інтерсервіс. 2016. C. 60-66.

11. Филипович Л. Релігійні і секулярні світи : проблеми взаємин 3 огляду на суспільні трансформації XXI ст. Історія релігій в Україні. 2019. Вип. 29. С. 192-197. 


\section{Анотація}

Мельничук В. В., Шевченко О. М. Трансформація релігійності в умовах урбанізації: соціально-філософський аналіз. - Стаття.

У статті досліджено особливості формування та трансформації релігійності в урбанізованому суспільстві. Доведено, що урбанізаційні процеси здійснюють вплив на буття людини та соціуму, в тому числі й на релігійну сферу. Навіть в умовах секуляризації, що характерна для урбанізованого суспільства, релігія не зникає, а трансформується. Відбувається, з одного боку, розділення сфери релігійного і світського, а з іншого - за необхідності релігія може залучатися до вирішення проблем, які знаходяться поза їі межами. Окреслену ситуацію можна охарактеризувати як постсекулярну, коли релігія під впливом соціальних обставин змінює свою функціональність, навіть здійснює вплив на ті сфери, від яких вона була відокремлена секуляризацією.

Проаналізовано окреслену проблематику в контексті розвитку українського суспільства. Обґрунтовано, що традиційна релігійність українців, яка здебільшого була орієнтована на сільський спосіб життя, не зовсім сприймається сучасним жителем міста. Проте це означає не зникнення релігійного складника духовності, а його трансформацію відповідно до потреб людини, адже релігія не втрачає своєї затребуваності.

Досліджено, що в умовах урбанізації релігійність характеризується такими рисами, як приватність, анонімність, вибірковість, пошуком нових форм і засобів задоволення релігійних потреб. Оскільки існування міських жителів здебільшого є раціонально обгрунтованим, орієнтованим на корисність, а спілкування характеризується поверховістю та швидкоплинністю, то релігія посідає чільне місце в житті людини як один із засобів подолання викликів, які постають перед нею в урбанізованому суспільстві. Показано, що релігійність набуває нових рис, адже людина сама вибирає час, місце, форми іiї вияву. За таких умов значного поширення набувають неорелігійні рухи, яким властива значна динамічність та гнучкість, що також притаманні міському способу життя. Вказано, що одним із процесів, який супроводжує урбанізацію, є віртуалізація, яка також впливає на релігійність, адже дає змогу сучасній людині реалізовувати свої релігійні потреби не за допомогою традиційних засобів, а у віртуальному вимірі.

Ключові слова: релігійність, релігія, урбанізація, міський спосіб життя, секуляризація, трансформація, суспільство.

\section{Summary}

Melnychuk V.V., Shevchenko O. M. Transformation of religiosity in the context of urbanization: socialphilosophical analysis. - Article.

The peculiarities of religiosity formation and transformation in an urban society are investigated in the article. It is proved that urbanization processes affect the existence of man and society, including religious sphere. Even in the conditions of secularization that is characteristic of urban society, religion does not disappear, but is transformed. There is, on the one hand, the division of the religious and secular, and, on the other - religion can be involved in solving problems that are outside it. This situation can be described as post-secular, when religion under the influence of social circumstances changes its own functions, even influences the areas from which it was separated by secularization.

This problem is analyzed in the context of Ukrainian society development. It is substantiated that traditional Ukrainians' religiosity was mostly focused on the rural way of life and is not completely perceived by a modern city resident. However, this does not mean religious disappearance, but its transformation according to the needs of a society, because religion does not lose its demand.

It is learnt that in the conditions of urbanization religiosity is characterized by following features: privacy, anonymity, selectivity, searching for new forms and means of satisfying religious needs. Since the existence of urban residents is mostly rational, useful, and communication is characterized by superficiality and ephemerality, religion occupies a prominent place in human life as one of means for overcoming the challenges facing them in an urban society. It is shown that religiosity acquires new features, because man himself chooses time, place, and forms of its manifestation. Under such conditions, neo-religious movements acquire a significant spread, and they are characterized by dynamics and flexibility, which is also inherent in the urban lifestyle. It is stated that one of the processes that accompany urbanization is virtualization, which is also affects religiosity, because it allows modern people to realize their own religious needs not by traditional means, but in the virtual world.

Key words: religiosity, religion, urbanization, urban way of life, secularization, transformation, society. 